\title{
The association between imbalances in vaginal microflora and duration of pregnancy as well as selected maternal and neonatal parameters
}

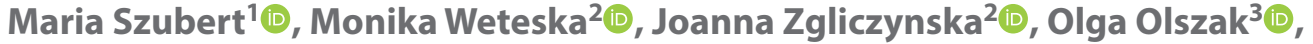 \\ Magdalena Zgliczynska4 ${ }^{4}$, Jaroslaw Kalinka ${ }^{3}$, Jacek R. Wilczynski ${ }^{1}$ \\ ${ }^{1}$ Department of Surgical and Oncologic Gynecology, $1^{\text {st }}$ Department of Gynecology and Obstetrics, \\ Medical University of Lodz, Poland \\ ${ }^{2}$ Student's Scientific Society, $1{ }^{\text {st }}$ Department of Gynecology and Obstetrics, Medical University of Lodz, Poland \\ ${ }^{3}$ Department of Perinatology, $1{ }^{\text {st }}$ Department of Gynecology and Obstetrics, Medical University of Lodz, Poland \\ ${ }^{4} 2^{\text {nd }}$ Department of Obstetrics and Gynecology, The Centre of Postgraduate Medical Education, Warsaw, Poland
}

\begin{abstract}
Objectives: Abnormal vaginal flora (AVF) is a result of excessive growth of some aerobic bacteria and fungi in relation to the scarce presence of Lactobacillus spp. It has been suggested that AVF is responsible for preterm birth and such neonatal conditions as infections or sepsis.

The aim of the study was to assess the influence of excessive vaginal colonization with aerobic bacteria and fungi on the selected postnatal parameters of newborns, duration of pregnancy and length of hospitalisation of neonates.

Material and methods: Retrospective data of all 1057 patients who delivered between 01.2019 and 06.2019 in the Department of Perinatology of Medical University of Lodz was analyzed. Eight hundred nine patients were included in this retrospective study. The study group consisted of 396 patients with abundant growth of aerobic bacteria and fungi obtained between 26 and 42 weeks of gestation, while 413 patients with physiologic vaginal biocenosis constituted the control group. Two hundred forty-eight patients (23.46\%) were excluded from the study due to incomplete data.

Results: Patients with abnormal vaginal flora (AVF) gave birth prematurely (9.09\%) more often than patients with balanced microflora (5.31\%), $p=0.038$. Newborns of mothers with AVF obtained an Apgar score under four more frequently $(1.21 \%$ vs $0 \% ; p=0.024)$. Eutrophic neonates were born less frequently in the study group $(82.08 \%$ vs $88.65 \% ; p=0.025)$. Hospitalisation period was longer for children of mothers with AVF (mean of $6.30 \pm 9.87$ days) than those of mothers from the control group (mean of $5.06 \pm 5.30$ ), $p=0.025$. Newborns of mothers with AVF developed perinatal infections more often $(23.97 \%$ vs $15.94 \% ; p=0.004)$. Four infants died in the study group whereas no deaths were recorded in the control group $(p=0.045)$. The most prevalent pathogens were: Streptococcus agalactiae (GBS) $57.32 \%$, Candida spp. $39.64 \%$, Klebsiella spp. $9.85 \%$, Staphylococcus aureus $7.32 \%$. Signs of infection were more frequently recorded in newborns of mothers infected with Klebsiella spp. (35.90\% vs $19.16 \% ; p=0.011)$. Premature birth was more prevalent in GBS carriers $(11.81 \%$ vs $6.28 \% ; p=0.022)$.

Conclusions: Abundant growth of aerobic bacteria in the 3rd trimester of gestation contributes to preterm birth, causes the development of infection signs in newborns, increases their mortality rate and prolongs hospitalisation period.
\end{abstract}

Key words: vaginal microflora; aerobic vaginitis; PROM

Ginekologia Polska 2021; 92, 9: 624-630

\section{INTRODUCTION}

The quantitative and qualitative composition of microorganisms in the vagina changes during a woman's life and depends on many factors such as, age, alterations in hormone levels (during the menstrual cycle, pregnancy, menopause), sexual intercourse and hygiene habits [1-3].
Due to the many improvements in modern microbiological diagnostics and findings of the Human Microbiome Project - a research initiative conducted by the National Institute of Health, our knowledge of the vaginal microflora has significantly increased [4]. Vaginal microbiota is dominated by Lactobacillus spp. (L. crispatus, L. iners, L.jensenii and L. gasseri)

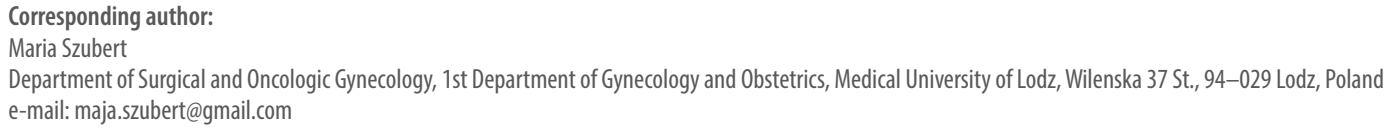


[5]. Lactobacillus species are responsible for the acidic $\mathrm{pH}$ of the vagina due to the production of lactic acid from glycogen stored in epithelial cells [2]. These symbiotic bacteria cover vaginal mucosa, preventing the adhesion and penetration of pathogens. Moreover, they produce hydrogen peroxide, bacteriocins and bacteriocin - like substances, which strengthen the mechanisms against invasion and colonization by opportunistic pathogens [1].

The pregnancy period is characterized by the exceptional stability of the vaginal microflora [5-7]. This balance is due to the increased estrogen levels, which provide an abundance of glycogen in epithelial cells, resulting in the proliferation of Lactobacilli $[1,5]$.

The most common anomalies associated with microbial imbalance in the vagina are bacterial vaginosis (BV), aerobic vaginitis (AV) and candidiasis. Bacterial vaginosis is a condition characterized by a rapid increase in the anaerobic bacteria population, at the expense of Lactobacilli. In this case, Prevotella, Mobiluncus, Gardnerella vaginalis, Ureaplasma and Mycoplasma are detected in vaginal smears. Traditionally we use Amsel's criteria in clinical settings $[8,9]$ however, Gram staining is the diagnostic standard [10]. Numerous studies confirm the impact of BV on the frequent occurrence of preterm premature rupture of membranes (PPROM), preterm birth [(PTB) delivery before 37 completed weeks of gestation] and low birth weight [(LBW) birth weight of less than 2500 ] [1, 11, 12].

Vaginal dysbiosis can also manifest as aerobic vaginitis (AV). In this case, reduction of the population of Lactobacilli and multiplying aerobic bacteria leads to inflammation [1]. The most common bacteria associated with $\mathrm{AV}$ and clinical features are presented in Table 1 [1, 13-15]. AV is associated with adverse obstetric outcomes including PPROM and PTB $[16,17]$. Maternal colonization with GBS in pregnant women during delivery could be associated with neonatal pneumonia, meningitis and even severe sepsis [18, 19]. Candidiasis is a fungal infection caused by any type of Candida. Pregnancy increases the frequency of vaginal Candida colonization, which is favored by high glycogen concentration, resulting from the influence of hormones [20]. The number of studies assessing the relationship between candidiasis and obstetric complications is not sufficient, and the results of many studies are inconclusive [21]. The most convincing analyses confirm the relationship between candidiasis (even asymptomatic colonization) and higher incidence rate of PTB and LBW [22-24].

Considering that the aforementioned pathologies are often asymptomatic, oligosymptomatic or symptoms may imitate physiological changes during pregnancy, and the fact that they have a significant impact on specific obstetric complications, it is important to actively screen for vaginal microflora disorders in pregnant women. Considering the importance of the balance in vaginal microflora during pregnancy we decided to perform a retrospective study to assess the influence of vaginal colonization with pathogenic bacteria and fungi on the adverse perinatal outcomes in mothers and newborns.

\section{Objectives}

The aim of the study was to assess the influence of excessive vaginal colonization with aerobic bacteria and fungi on the selected parameters of newborns, duration of pregnancy and length of hospitalisation of neonates.

\begin{tabular}{|c|c|c|c|}
\hline & Bacterial vaginosis & Aerobic vaginitis & Candidiasis \\
\hline Etiology & $\begin{array}{c}\text { Prevotella, } \\
\text { Mobiluncus, } \\
\text { Gardnerella vaginalis, Ureaplasma, } \\
\text { Mycoplasma }\end{array}$ & $\begin{array}{l}\text { Escherichia coli, Enterococcus } \\
\text { faecalis, Staphylococcus aureus, } \\
\text { Staphylococcus epidermidis, } \\
\text { group B Streptococcus }\end{array}$ & $\begin{array}{l}\text { Candida albicans, } \\
\text { rarely other Candida species }\end{array}$ \\
\hline Vaginal discharge & $\begin{array}{l}\text { thin, homogenous, } \\
\text { mostly white or gray }\end{array}$ & yellowish and sticky & thick or cheesy white \\
\hline Odor & $\begin{array}{l}\text { fishy smell, especially } \\
\text { when reacting with } \mathrm{KOH}\end{array}$ & devoid of fishy smell & no odor \\
\hline $\mathrm{pH}$ & $>4.5$ & $>6$ & $<4.5$ \\
\hline Features of inflammation & often absent, no inflammation & present, often severe & $\begin{array}{l}\text { present, mostly vulvar } \\
\text { erythema and oedema }\end{array}$ \\
\hline $\begin{array}{l}\text { Influence on obstetric } \\
\text { complications }\end{array}$ & PPROM, LBW, PTB & PPROM, PTB & LBW, PTB (inconclusive data) \\
\hline Risk factors & $\begin{array}{l}\text { low socioeconomic status, vaginal } \\
\text { douching, smoking, multiple sex } \\
\text { partners, unprotected intercourse }\end{array}$ & $\begin{array}{c}\text { unmarried status, long-term use } \\
\text { of antibiotics, frequent vaginal } \\
\text { douching }\end{array}$ & $\begin{array}{l}\text { recent antibiotic use, diabetes } \\
\text { mellitus, AIDS, corticosteroid use, } \\
\text { immunosuppression }\end{array}$ \\
\hline
\end{tabular}

$\mathrm{KOH}$ - potassium hydroxide; AIDS — acquired immune deficiency syndrome; PPROM — preterm premature rupture of membranes; LBW — low birth weight; PTB - preterm birth 


\section{MATERIAL AND METHODS}

Out of 1057 patients who gave birth in the Pirogow Clinical Hospital in Lodz between January and June 2019, there were 809 patients included in this retrospective study. Those patients had their vaginal flora sampled upon hospital admission for delivery. In the given timeline patients gave birth between 26 and 42 weeks of gestation. Swabs were taken from the posterior vaginal wall. Next, smears and bacterial staining were performed, followed by microscopic evaluation. The microscopic evaluation consisted of assessing the Lactobacillus count, presence of other bacteria and fungi and leukocyte count. Based on the results, patients were divided into two groups. Patients whose smears did not reveal any abnormalities in bacterial or fungal growth and had high Lactobacillus count constituted the control group - 413 patients. The study group consisted of 396 patients whose smears revealed abnormalities (low Lactobacillus count, abundant growth of other bacteria and fungi), which will be referred to in the article as abnormal vaginal flora (AVF). The abnormal result was considered an indication to obtain bacterial or fungal cultures. Depending on the species, microorganisms were cultivated between 18-96 hours. The isolated bacteria and fungi were assessed for antimicrobial drug sensitivity using a disk diffusion test. The results were uploaded to an online database. All the patients in the study group and the control group were also tested for GBS presence through rectal and vaginal swabbing. Patients who were not tested for GBS, regardless of their flora composition were excluded from the study as well as patients tested for GBS but not tested for other abundant bacterial or fungal growth -248 patients (23.46\%).

Baseline characteristics and past medical and obstetric history of subjects - age, parity, gravity as well as data concerning the pregnancy in question: way of delivery (C-section/natural birth/forceps or vacuum), gestational age during delivery and the occurrence of PROM were taken. In addition, characteristics of neonates born to mothers enrolled in the study were obtained in order to assess neonatal well-being and post-delivery condition. The characteristics were: neonatal birth weight, Apgar score after the $1^{\text {st }}, 3^{\text {rd }}, 5^{\text {th }}$ $10^{\text {th }}$ minute after birth, signs of infection in the neonates, signs of respiratory distress, hypotonia, positive bacterial blood culture and the length of post-delivery hospitalisation of the neonates. The following criteria were used as to indicate signs of infection in neonates based on Chan et al. [25], elevated C-reactive protein (CRP) - over 10mg/L and white blood count (WBC) - over 30 000/ $\mu \mathrm{L}$, fever, positive bacterial or fungal blood culture. Respiratory distress was defined using the criteria by Liu et al. and Sochocka et al.: labored breathing (retractions of intercostal muscles, nasal flaring), crackles on auscultation, pulmonary oedema, the necessity to use mechanical ventilatory support, typical $x$-ray chest findings (diffuse alveolar opacification), metabolic and mixed acidosis or hypoxia/hypercapnia in blood tests $[26,27]$.

Microsoft Excel 365 (Microsoft, Redmond, Washington, United States of America) and STATISTICA 13.3. (TIBCO Software, Palo Alto, California, United States of America) software were used for statistical analysis. Descriptive data was presented as numbers, percentages, and means with standard deviations. The statistical significance of the association between events was determined with the use of $\mathrm{Chi}^{2}$ Pearson test. In addition, due to the large study group and the assumed normal distribution of variables, statistical differences in numerical variables were determined using parametric tests, namely the student's T test. P-values were represented to three decimal numbers and 0.05 was used as a cutoff for significance.

\section{RESULTS}

Out of the 1057 patients delivered in our hospital between January 2019 and June 2019, a total of 827 underwent vaginal discharge sampling upon hospital admission for delivery (between 26 and 42 weeks of gestation). AVF was observed in the case of 396 patients while 413 had physiological composition of vaginal flora (abundance of Lactobacillus spp., scarce or no other bacterial species, absence of no leukocytes and fungi).

The maternal characteristics are presented in Table 2 . There was no significant difference in maternal age, gravity and parity between groups. There was however, statistically significant difference in gestational age between both groups (38.63 vs 38.95 gestational weeks).

Table 2. Basic characteristics of pregnant women

\begin{tabular}{|l|c|c|c|}
\hline Variable & $\begin{array}{c}\text { Study group } \\
(\mathbf{n = 3 9 6 )}\end{array}$ & $\begin{array}{c}\text { Control group } \\
\text { (n= 413) }\end{array}$ & p value \\
\hline Maternal age [years] & $31.32 \pm 5.23$ & $31.74 \pm 4.59$ & 0.234 \\
\hline Gestational age [weeks] & $38.63 \pm 2.08$ & $38.95 \pm 1.58$ & 0.012 \\
\hline Gravity [median] & $2 \pm 0.92$ & $2 \pm 0.94$ & 0.243 \\
\hline Parity [median] & $1 \pm 0.82$ & $1 \pm 0.69$ & 0.053 \\
\hline
\end{tabular}




\begin{tabular}{|l|c|c|c|}
\hline \multicolumn{2}{|l|}{ Table 3. Delivery data analysis } & & \\
\hline Variable & Study group & Control group & p value \\
\hline Preterm birth (<37 weeks) & $9.09 \%$ & $5.31 \%$ & 0.038 \\
\hline Vaginal delivery & $46.97 \%$ & $49.15 \%$ & 0.534 \\
\hline Cesarean section & $50.76 \%$ & $48.18 \%$ & 0.464 \\
\hline Forceps/vacuum delivery & $2.27 \%$ & $2.66 \%$ & 0.721 \\
\hline PROM & $30.30 \%$ & $27.12 \%$ & 0.317 \\
\hline
\end{tabular}

PROM - premature rupture of membranes

\begin{tabular}{|c|c|c|c|}
\hline Variable & Study group & Control group & p-value \\
\hline Apgar $<8$ & $5.57 \%$ & $2.9 \%$ & 0.056 \\
\hline Apgar $<4$ & $1.21 \%$ & $0 \%$ & 0.024 \\
\hline Hypotrophy & $10.17 \%$ & $7.08 \%$ & 0.104 \\
\hline Eutrophy & $82.08 \%$ & $88.65 \%$ & 0.025 \\
\hline Hypertrophy & $7.75 \%$ & $4.35 \%$ & 0.057 \\
\hline Signs of infection & $23.97 \%$ & $15.94 \%$ & 0.004 \\
\hline Respiratory distress & $9.44 \%$ & $7.97 \%$ & 0.453 \\
\hline Hypotonia & $2.18 \%$ & $2.42 \%$ & 0.820 \\
\hline Length of post-delivery hospitalisation [days] & $6.30( \pm 9.87)$ & $5.06( \pm 5.30)$ & 0.025 \\
\hline Positive bacterial blood culture (if taken) & $11.11 \%(n=45)$ & $10.00 \%(n=18)$ & 0.018 \\
\hline Neonatal deaths & $n=4$ & $n=0$ & 0.045 \\
\hline
\end{tabular}

Delivery data analysis is presented in Table 3. Premature birth ( $26+0-36+6$ weeks of gestation) occurred significantly more often in the study group ( $9.09 \%$ vs $5.31 \%$; $p=0.038$ ).

Neonatal parameters are presented in Table 4. When compared, an Apgar score $<4$ signifying bad condition was recorded only in infants of mothers from the study group (1.21\% vs $0 \% ; p=0.02210$ ).

Neonatal assessment also included birth weight analysis which is presented in Table 4. Hypotrophy was more prevalent in the study group $(10.17 \%$ vs $7.08 \%)$, but the difference was not statistically significant $(p=0.104)$. On the other hand, eutrophy was observed less often in the study group ( $82.08 \%$ vs $88.65 \% ; p=0.025)$. Hypertrophy occurred more often in the study group; however, the difference was insignificant ( $7.75 \%$ vs $4.35 \% ; p=0.057$ ).

Figure 1 represents the prevalence of infection signs among neonates. As shown on the graph, infants born to mothers from the study group developed infections statistically more often than infants born to mothers from the control group ( $23.97 \%$ vs $15.94 \% ; p=0.004)$.

There was no significant difference in the development of respiratory distress or hypotonia among infants of both groups.
Regarding perinatal mortality, it was significantly more frequent in the study group - four children of mothers with AVF died, while no deaths were recorded in the control group ( $p=0.045$ ). Due to severe post-delivery conditions, two children of mothers from the study group were admitted to the Intensive Care Unit, whereas there was no such necessity for children of mothers from the control group.

Among children of patients with abnormal microflora the average length of hospital stay was 6.30 ( \pm 9.87$)$ days while for children of patients whose microflora did not show any abnormalities, the length was calculated as $5.06( \pm 5.30)$, $(p=0.025)$.

As for microbiological results, 15 bacteria and fungi species were cultivated from the smears and are presented in Table 5. The most common abundant pathogen growth cultivated from the samples was GBS - $57.32 \%$, followed by Candida spp. - 39.64\% and Klebsiella spp. - 9.85\%, two or more pathogens were cultivated from the samples of 104 patients (26.26\%).

In the aim of assessing whether any specific type of microbial growth affected neonatal well-being we analyzed such parameters as: signs of infection in newborns, preterm 


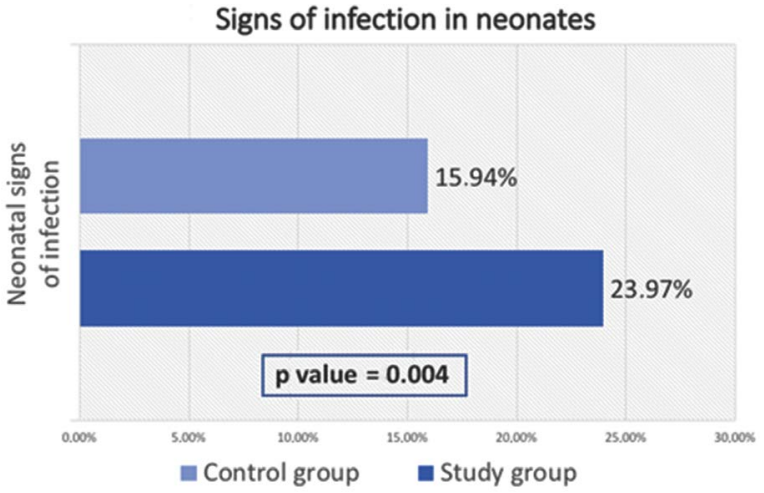

Figure 1. Prevalence of infection signs among neonates

\begin{tabular}{|l|l|}
\hline \multicolumn{2}{|l|}{ Table 5. Results of cultures in the study group } \\
\hline Pathogen & $\begin{array}{c}\text { Presence in } \% \text { in genital } \\
\text { tract in the 3 }\end{array}$ \\
\hline Streptococcus agalactiae (GBS) & $57.32 \%$ \\
\hline Candida spp. & $39.64 \%$ \\
\hline Klebsiella spp. & $9.85 \%$ \\
\hline Staphylococcus aureus & $7.32 \%$ \\
\hline Proteus spp. & $2.78 \%$ \\
\hline Enterococcus spp. & $2.27 \%$ \\
\hline Escherichia coli spp. & $2.02 \%$ \\
\hline Pseudomonas spp. & $1.52 \%$ \\
\hline Morganella spp. & $1.52 \%$ \\
\hline Saccharomyces & $1.52 \%$ \\
\hline Citrobacter & $1.26 \%$ \\
\hline Enterobacter & $1.26 \%$ \\
\hline Serratia & $<1 \%$ \\
\hline Streptococcus group C & $<1 \%$ \\
\hline Leclercia adecarboxylata & $<1 \%$ \\
\hline GBS - Streptococcus agalactiae & \\
\hline
\end{tabular}

delivery rate, respiratory distress and reduced Apgar score and calculated correlations between the above mentioned and the prevalence of certain species in the genital tract. Our results are presented in Table 6, 7 and 8.

Signs of infection in newborns: elevated CRP - over $10 \mathrm{mg} / \mathrm{L}$ and WBC — over $30000 / \mu \mathrm{L}$, fever, positive bacterial or fungal blood culture [25].

The influence of specific bacterial and fungal strains on the occurrence of preterm birth is presented in Table 7.The results showed that the incidence of preterm birth $(26+0-36+6$ weeks) was higher among patients infected with GBS than those not infected ( $p=0.022)$.

The results shown in Table 8 . indicate that the presence of Klebsiella spp. in the genital tract is associated with a higher incidence of postnatal respiratory distress in newborns $(p=0.036)$.

\begin{tabular}{|c|c|c|}
\hline Pathogen type & Signs of infection in newborn & p value \\
\hline $\begin{array}{l}\text { Klebsiella spp. } \\
\text { present } \\
\text { absent }\end{array}$ & $\begin{array}{l}35.90 \% \\
19.16 \%\end{array}$ & 0.011 \\
\hline $\begin{array}{l}\text { GBS } \\
\text { present } \\
\text { absent }\end{array}$ & $\begin{array}{l}22.78 \% \\
18.81 \%\end{array}$ & 0.196 \\
\hline $\begin{array}{l}\text { S. aureus } \\
\text { present } \\
\text { absent }\end{array}$ & $\begin{array}{l}20.69 \% \\
19.92 \%\end{array}$ & 0.919 \\
\hline $\begin{array}{l}\text { Candida spp. } \\
\text { present } \\
\text { absent }\end{array}$ & $\begin{array}{l}22.21 \% \\
19.64 \%\end{array}$ & 0.651 \\
\hline
\end{tabular}

GBS - Streptococcus agalactiae

Table 7. Incidence of preterm delivery $(26+0-36+6$ weeks $)$ according to the type of vaginal microflora cultivated from the smears

\begin{tabular}{|l|c|c|}
\hline Pathogen type & Preterm delivery & p value \\
\hline $\begin{array}{l}\text { Klebsiella spp. } \\
\text { present } \\
\text { absent }\end{array}$ & $\begin{array}{c}12.82 \% \\
7.62 \%\end{array}$ & 0.253 \\
\hline $\begin{array}{l}\text { GBS } \\
\text { present } \\
\text { absent }\end{array}$ & $11.81 \%$ & 0.022 \\
\hline $\begin{array}{l}\text { S. aureus } \\
\text { present } \\
\text { absent }\end{array}$ & $6.28 \%$ & \\
\hline $\begin{array}{l}\text { Candida spp. } \\
\text { present } \\
\text { absent }\end{array}$ & $6.90 \%$ & 0.823 \\
\hline
\end{tabular}

GBS - Streptococcus agalactiae

Table 8. Incidence of respiratory distress signs in newborns according to the type of cultivated microflora

\begin{tabular}{l|l|l|}
\hline Pathogen type & $\begin{array}{r}\text { Respiratory distress signs } \\
\text { in newborn }\end{array}$ & p value \\
\hline $\begin{array}{l}\text { Klebsiella spp. } \\
\text { present } \\
\text { absent }\end{array}$ & $\begin{array}{l}18.00 \% \\
8.26 \%\end{array}$ & 0.036 \\
\hline $\begin{array}{l}\text { GBS } \\
\text { present } \\
\text { absent }\end{array}$ & $9.70 \%$ & \\
\hline $\begin{array}{l}\text { S. aureus } \\
\text { present }\end{array}$ & $8.32 \%$ & 0.519 \\
absent & $6.90 \%$ & \\
\hline $\begin{array}{l}\text { Candida spp. } \\
\text { present } \\
\text { absent }\end{array}$ & $8.78 \%$ & 0.725 \\
\hline
\end{tabular}

GBS - Streptococcus agalactiae

There was no relationship between an Apgar score below 8 and presence of specific bacteria or fungi cultures in the mother's genital tract. 


\section{DISCUSSION}

The balance in the vaginal microflora is essential for maintaining a healthy vaginal environment and preventing colonization with opportunistic pathogens. Insufficient Lactobacilli growth enables bacteria and fungi to thrive and grow abundantly which may cause signs of infection in pregnant females, result in perinatal complications and have consequences on the well-being of their newborns [16, 28]. $\mathrm{AV}$ is a newly established condition characterized by the imbalance in the microflora accompanied by an increased inflammatory reaction and followed by a consequential immune response [28]. In addition, the imbalances in the microflora facilitate the invasion and growth of fungi such as Candida [15].

Our results showed that patients with abnormal bacterial or fungal growth delivered prematurely more often than those not infected. However, our study included patients who gave birth between 26 and 42 weeks of gestation as this was the specificity of patients admitted to the department in the given timeline. Thus, we only proved a connection between AVF and preterm birth between $26+0$ and $36+6$ weeks of gestation. According to literature [29], GBS is significantly associated with preterm birth which was also confirmed in our study. Interestingly, there was no statistical correlation between PTB and Klebsiella spp., S. aureus or Candida spp. infection. It is well known that the occurrence of PTB is a result of multiple factors, but they were not considered in this study as our prime focus was the influence of vaginal flora.

Many studies confirm that abnormal vaginal flora is associated with deterioration of newborn's condition and need for intensive care for neonates [28]. In our study we confirmed that it is also connected to reduced Apgar score. Abnormal vaginal flora may contribute to the development of signs of infection in the newborns [30]. In our study infants born to mothers with disturbed balance in vaginal microbiota developed infections statistically more often than infants born to mothers without abnormalities.

Special attention should be paid to abundant growth of Klebsiella spp. Many sources indicate that Klebsiella spp. has a considerable impact on the occurrence of neonatal infections. According to Omwandho et al. [31], this strain of bacteria accounted for over $50 \%$ of bacterial infections among neonates and was responsible for $70 \%$ of neonatal deaths. Our study recorded a higher incidence of neonatal infections among newborns of mothers infected or colonized with Klebsiella as well as a connection between the infection with this pathogen and signs of respiratory distress in newborns.

Due to the recognized impact of GBS on the pregnancy outcomes, screening for GBS is recommended during the last trimester of pregnancy, generally between 35 and 37 weeks of gestation [32]. In addition, antibiotic prophylaxis should be administered to GBS colonized women perinatally [32]. Although there is an evidence of the harmful impact of Klebsiella on neonatal well-being, there are no similar recommendations and procedures for patients infected with this bacterium [33]. The prevalence of abnormalities in vaginal microbiota correlated with longer post-delivery hospitalisation. Prolonged hospitalisation of infants, especially those born in bad condition generates higher costs [34]. Regarding the prevention of $A V$ and associated bacterial and fungal colonization, Nv Geneg et al., emphasize that consistent condom uses and college-level education is a protective factor for AV. Unmarried status, menarche at 13-15 years, Intrauterine device (IUD) use, long-term use of antibiotics, use of panty liners and frequent vaginal douching are listed as risk factors [35].

Our study has some limitations. First, the retrospective nature of the study did not allow us to assess the clinical symptoms of vaginitis in patients. Secondly, we were not able to assess the immunological and biochemical characteristics of patients' vaginal discharge which is why the diagnosis of AV could be argued. Our study was conducted in a gynecologic hospital in a big city which does not reflect the general Polish population. Multicenter studies are therefore needed for comparison. As strengths of our study, we consider the big number of patients in the study group - all patients hospitalized after their $30^{\text {th }}$ week of pregnancy in our department in the chosen timeline were included in the analysis.

\section{CONCLUSIONS}

We proved a connection between abundant growth of aerobic bacteria in the $3^{\text {rd }}$ trimester of gestation and preterm birth, the development of infection signs in newborns, an increase in their mortality and extension of hospitalisation period. Preventive measures such as screening tests should be carried out regularly and efficient follow-up should be implemented. Those measures should be taken into consideration particularly in the case of Klebsiella spp. growth as it was proven to contribute to the development of signs of infection and respiratory distress in newborns.

\section{Author contributions}

Conceptualization, M.S., M.W., J.Z., and O.O.; Methodology, M.S., M.W., J.Z, M.Z.; Formal Analysis, M.S., M.W., J.Z., M.Z.; Investigation, M.S., M.W., J.Z and O.O.; Resources, M.S., J.K., J.W.; Data Curation, M.S., O.O;Writing - Original Draft Preparation, M.W, J.Z., O.O., M.Z.; Writing - Review \& Editing, M.S. and J.W.; Supervision, J.K., J.W.; All authors have read and agreed to the published version of the manuscript. 


\section{Conflict of interest}

The authors declare that they have no conflict of interest.

\section{REFERENCES}

1. Amabebe $\mathrm{E}$, Anumba DOC. The Vaginal Microenvironment: The Physiologic Role of . Front Med (Lausanne). 2018; 5: 181, doi: 10.3389/fmed.2018.00181, indexed in Pubmed: 29951482.

2. Kaambo E, Africa C, Chambuso R, et al. Vaginal Microbiomes Associated With Aerobic Vaginitis and Bacterial Vaginosis. Front Public Health. 2018; 6: 78, doi: 10.3389/fpubh.2018.00078, indexed in Pubmed: 29632854.

3. Larsen B, Monif GR. Understanding the bacterial flora of the female genital tract. Clin Infect Dis. 2001; 32(4): e69-e77, doi: 10.1086/318710, indexed in Pubmed: 11181139.

4. Turnbaugh PJ, Ley RE, Hamady M, et al. The human microbiome project. Nature. 2007; 449(7164): 804-810, doi: 10.1038/nature06244, indexed in Pubmed: 17943116.

5. Romero R, Hassan SS, Gajer P, et al. The composition and stability of the vaginal microbiota of normal pregnant women is different from that of non-pregnant women. Microbiome. 2014; 2(1): 4, doi: 10.1186/20492618-2-4, indexed in Pubmed: 24484853.

6. Maclntyre DA, Chandiramani M, LeeYS, et al. The vaginal microbiome during pregnancy and the postpartum period in a European population. Sci Rep. 2015; 5: 8988, doi: 10.1038/srep08988, indexed in Pubmed: 25758319.

7. DiGiulio DB, Callahan BJ, McMurdie PJ, et al. Temporal and spatial variation of the human microbiota during pregnancy. Proc Natl Acad Sci U S A. $2015 ; 112$ (35): 11060-11065, doi: 10.1073/pnas.1502875112, indexed in Pubmed: 26283357.

8. Turovskiy Y, Sutyak Noll K, Chikindas ML. The aetiology of bacterial vaginosis. J Appl Microbiol. 2011; 110(5): 1105-1128, doi: 10.1111/j.13 65-2672.2011.04977.x, indexed in Pubmed: 21332897.

9. Reiter S, Kellogg Spadt S. Bacterial vaginosis: a primer for clinicians. Postgrad Med. 2019; 131(1): 8-18, doi: 10.1080/00325481.2019.1546534, indexed in Pubmed: 30424704.

10. Heather $L$, et al. Paladine, Vaginitis: Diagnosis and Treatment. Am Fam Physician. 2018; 97(5): 321-329.

11. Klebanoff MA, Hillier SL, Nugent RP, et al. National Institute of Child Health and Human Development Maternal-Fetal Medicine Units Network. Is bacterial vaginosis a stronger risk factor for preterm birth when it is diagnosed earlier in gestation? Am J Obstet Gynecol. 2005; 192(2): 470-477, doi: 10.1016/j.ajog.2004.07.017, indexed in Pubmed: 15695989.

12. Bretelle F, Rozenberg P, Pascal A, et al. Groupe de Recherche en Obstetrique Gynecologie. High Atopobium vaginae and Gardnerella vaginalis vaginal loads are associated with preterm birth. Clin Infect Dis. 2015; 60(6): 860-867, doi: 10.1093/cid/ciu966, indexed in Pubmed: 25452591.

13. Donders $G$. Definition and classification of abnormal vaginal flora. Best Pract Res Clin Obstet Gynaecol. 2007; 21(3): 355-373, doi: 10.1016/j. bpobgyn.2007.01.002.

14. Donders GGG, Vereecken A, Bosmans E, et al. Definition of a type of abnormal vaginal flora that is distinct from bacterial vaginosis: aerobic vaginitis. BJOG. 2002; 109(1): 34-43, doi: 10.1111/j.1471-0528.2002.00 432.x, indexed in Pubmed: 11845812.

15. $\mathrm{Han} \mathrm{C}, \mathrm{LiH}, \mathrm{Han} \mathrm{L}$, et al. Aerobic vaginitis in late pregnancy and outcomes of pregnancy. Eur J Clin Microbiol Infect Dis. 2019; 38(2): 233-239, doi: 10.1007/s10096-018-3416-2, indexed in Pubmed: 30467614.

16. Donders G, Bellen G, Rezeberga D. Aerobic vaginitis in pregnancy. BJOG. 2011; 118(10): 1163-1170, doi: 10.1111/j.1471-0528.2011.0302 0.x, indexed in Pubmed: 21668769.

17. Vieira-Baptista $P$, Lima-Silva J, Pinto $C$, et al. Bacterial vaginosis, aerobic vaginitis, vaginal inflammation and major Pap smear abnormalities. Eur J Clin Microbiol Infect Dis. 2016; 35(4): 657-664, doi: 10.1007/s10096016-2584-1, indexed in Pubmed: 26810061.

18. Oeser $C$, Pond $M$, Butcher $P$, et al. $P C R$ for the detection of pathogens in neonatal early onset sepsis. PLoS One. 2020; 15(1): e0226817, doi: 10.1371/journal.pone.0226817, indexed in Pubmed: 31978082
19. Hasperhoven GF, Al-Nasiry S, Bekker V, et al. Universal screening versus risk-based protocols for antibiotic prophylaxis during childbirth to prevent early-onset group B streptococcal disease: a systematic review and meta-analysis. BJOG. 2020; 127(6): 680-691, doi: 10.1111/14710528.16085, indexed in Pubmed: 31913562.

20. Sobel J. Vulvovaginal candidosis. The Lancet. 2007; 369(9577): 19611971, doi: 10.1016/s0140-6736(07)60917-9.

21. Roberts $\mathrm{CL}$, Algert $\mathrm{CS}$, Rickard $\mathrm{KL}$, et al. Treatment of vaginal candidiasis for the prevention of preterm birth: a systematic review and meta-analysis. Syst Rev. 2015; 4: 31, doi: 10.1186/s13643-015-0018-2, indexed in Pubmed: 25874659.

22. Roberts $\mathrm{CL}$, Algert $\mathrm{CS}$, Rickard KL, et al. Treatment of vaginal candidiasis for the prevention of preterm birth: a systematic review and meta-analysis. Syst Rev. 2015; 4: 31, doi: 10.1186/s13643-015-0018-2, indexed in Pubmed: 25874659.

23. Farr $\mathrm{A}$, Kiss $\mathrm{H}$, Holzer l, et al. Effect of asymptomatic vaginal colonization with Candida albicans on pregnancy outcome. Acta Obstet Gynecol Scand. 2015; 94(9): 989-996, doi: 10.1111/aogs.12697, indexed in Pubmed: 26084843

24. Maki $Y$, Fujisaki $M$, Sato $Y$, et al. Candida Chorioamnionitis Leads to Preterm Birth and Adverse Fetal-Neonatal Outcome. Infectious Diseases in Obstetrics and Gynecology. 2017; 2017: 1-11, doi: 10.1155/2017/9060138.

25. Chan GJ, Lee ACC, Baqui AH, et al. Risk of early-onset neonatal infection with maternal infection or colonization: a global systematic review and meta-analysis. PLoS Med. 2013; 10(8): e1001502, doi: 10.1371/journal. pmed.1001502, indexed in Pubmed: 23976885.

26. Liu J, Shi Y, Dong Jy, et al. Clinical characteristics, diagnosis and management of respiratory distress syndrome in full-term neonates. Chin Med J (Engl). 2010; 123(19): 2640-2644, indexed in Pubmed: 21034645.

27. Sochocka L, Kędra E, Bensz D. Planowanie opieki pielęgniarskiej nad urodzonym przedwcześnie noworodkiem z zaburzeniami oddychania, wentylowanym mechanicznie. Studium przypadku. Pielęgniarstwo Polskie. 2017; 64(2): 338-345, doi: 10.20883/pielpol.2017.46.

28. Hassan MF, Rund NMA, El-Tohamy O, et al. Does Aerobic Vaginitis Have Adverse Pregnancy Outcomes? Prospective Observational Study. Infect Dis Obstet Gynecol. 2020; 2020: 5842150, doi: 10.1155/2020/5842150, indexed in Pubmed: 32395067.

29. Bianchi-Jassir F, Seale AC, Kohli-Lynch M, et al. Preterm Birth Associated With Group B Streptococcus Maternal Colonization Worldwide: Systematic Review and Meta-analyses. Clin Infect Dis. 2017; 65(suppl_2): S133-S142, doi: 10.1093/cid/cix661, indexed in Pubmed: 29117329.

30. Oh $\mathrm{KY}$, Jin $\mathrm{CH}$, Sohn $\mathrm{YH}$, et al. The prevalence of abnormal vaginal flora and predictive factors for intrauterine infection in pregnant Korean women with preterm labor. Clin Exp Obstet Gynecol. 2017; 44(3): 429-433, indexed in Pubmed: 29949287.

31. Omwandho COA, Gruessner SEM, Tinneberg HR. Early pregnancy loss and neonatal deaths associated with Klebsiella pneumonia infection: a mini review of possible occupational health risk. Arch Gynecol Obstet. 2006; 273(5): 258-260, doi: 10.1007/s00404-005-0081-3, indexed in Pubmed: 16273411

32. Di Renzo GC, Melin P, Berardi A, et al. Intrapartum GBS screening and antibiotic prophylaxis: a European consensus conference. J Matern Fetal Neonatal Med. 2015; 28(7): 766-782, doi: 10.3109/14767058.2014.934804, indexed in Pubmed: 25162923.

33. Cisse CT, Mbengue-Diop R, Moubarek $M$, et al. [Neonatal bacterial infections at the CUH of Dakar]. Gynecol Obstet Fertil. 2001; 29(6): 433-439, doi: 10.1016/s1297-9589(01)00157-6, indexed in Pubmed: 11462959.

34. Ogata JF, Fonseca MC, Miyoshi MH, et al. Costs of hospitalization in preterm infants: impact of antenatal steroid therapy. J Pediatr (Rio J). 2016; 92(1): 24-31, doi: 10.1016/j.jped.2015.03.004, indexed in Pubmed: 26133238.

35. Geng Nv, Wu W, Fan A, et al. Analysis of the Risk Factors for Aerobic Vaginitis: A Case-Control Study. Gynecol Obstet Invest. 2015 [Epub ahead of print], doi: 10.1159/000431286, indexed in Pubmed: 26068172. 